INSTITUTE OF FORESTRY • BELGRADE

INSTITUT ZA ŠUMARSTVO • BEOGRAD

SUSTAINABLE FORESTRY

COLLECTION 79-80, 2019
ODRŽIVO ŠUMARSTVO

ZBORNIK RADOVA 79-80, 2019

UDK 502.3/.5:55(597.11 Novi Pazar)

Original scientific paper

\title{
GEOLOGICAL SUBSTRATE OF THE TERRITORY OF NOVI PAZAR AS AN INDICATOR OF PRESERVED ENVIRONMENT
}

\author{
Sabahudin HADROVIĆl, Ljubinko RAKONJAC ${ }^{l}$, \\ Aleksandar LUČI $\dot{C}^{l}$, Saša EREMIJA ${ }^{l}$
}

\begin{abstract}
We strive to live in a healthy environment and to keep the entire food chain unpolluted and free of all unwanted contaminants. The care for humans cannot be considered partially if at the same time we do not succeed in a fight for unpolluted environment for flora and fauna. Likewise, we need to be well aware of environmental conditions and benefits they provide us with for better quality and healthier living in a particular area. Certainly, each territory has its own characteristics caused by environmental conditions. In geological terms, the territory of Novi Pazar is special in its characteristics since in this area Vardar zone faces Dinaric zone, where both have an impact on the quality of the environment. Knowing the property of parent material that by its dissolution it gives elements which reach lithosphere, hydrosphere and atmosphere and through the food chain they circulate from plants, animals to humans, it is necessary to intensify the study of the properties of geological substrate as an indicator of preserved and healthy environment.
\end{abstract}

Key words: Novi Pazar, geological substrate, environment

\section{GEOLOŠKA PODLOGA PODRUČJA NOVOG PAZARA KAO INDIKATOR OČUVANE ŽIVOTNE SREDINE}

Izvod: Trudimo se da živimo u zdravoj životnoj sredini $i$ da ceo lanac u ishrani bude nezagađen $i$ oslobođen svih neželjenih primesa. Briga za čoveka ne može se parcijalno posmatrati, ako se istovremeno ne izborimo da imamo nezagađenu sredinu za biljni i životinjski svet. Isto tako moramo dobro poznavati ekološke uslove i prednosti koje nam oni pružaju za kvalitetniji i zdraviji život na određenom prostoru. Naravno da svako područje ima svoje karakteristike uslovljene ekološkim uslovima. Područje Novog Pazara u

${ }^{1}$ Institute of Forestry, 3 Kneza Višeslava, Belgrade, Serbia 
geološkom smislu je karakteristično, jer se na ovom prostoru susreću Vardarska i Dinarska zona, gde jedna i druga imaju uticaj na kvalitet životne sredine. Poznavajući svojstva matičnog supstrata, da svojim rastvaranjem daje elemente koji dospevaju u litosveru, hidrosferu $i$ atmosferu $i$ da kroz lanac ishrane, oni kruže od biljaka, životinja do čoveka, neophodno je intenzivirati proučavanja svojstava geološke podloge kao indikatora očuvane i zdrave životne sredine.

Ključne reči: Novi Pazar, geološka podloga, životna sredina

\section{INTRODUCTION}

The global concept of sustainable management of natural resources has an important environmental and social economic dimension, and it is developed as a result of growing awareness of the impact of activities of humans on the environment. According to Komatina (1999), geological substrate is of great importance to the whole flora and fauna, and it is reflected depending on the composition of parent material.

Natural regeneration of forest areas, as well as the choice of methods of natural regeneration, depend most on ecological (habitat) conditions, among which heterogeneity of geological base is very often a decisive factor (Čokeša et al, 2006).

The researched territory is characterized by the diversity of parent material, which reflects the presence of a large number of different types of rocks. The geological substrate of the territory of Novi Pazar is special in its characteristics since in this area Vardar zone faces Dinaric zone.

In the territory of Novi Pazar, there are, as everywhere, small sins against the nature. In the first place there is a very often occurrence of forest fires, or a poor decision to form Golo Brdo city dump on the spring of the Josanica river in a Common Spruce stand at the altitude of 1300 meters. After a certain period of time, all this affects negatively the geological substrate and other environmental factors.

\section{MATERIAL AND METHODS}

The researched territory is situated in southwestern Serbia, in stellate valley of the Josanica, the Raska, the Dezevska, the Trnavska and the Ljudska rivers at the altitude of 496 meters, surrounded by high mountains Golija, Rogozna, Turjak, Crni Vrh, and Pester plateau.

For this paper, data from literature related to the territory of Novi Pazar and wider area of Pester and Kopaonik are used. Data on the composition of geological substrate are taken from Basic Geological Map 1:100.000 - sheets Sjenica (Mojsilovic et al., 1979) and Novi Pazar (Urosevic et al., 1970), as well as the data from General Forest Management Plan for the forest area "Gornji Ibar".

To study the content of documents, content analysis was applied as a kind of partial analysis (Milosavljević, Radosavljević, 2008). Some authors (Bulmer, 1977; Neuman, 2014) classify content analysis into a group of nonreactive methods since it does not involve direct elicitation of data from the research subjects. The 
respondents are not aware of the research, unlike questionnaires, interviews, and experiments, which are reactive methods (Neuman, 2014).

\section{RESULTS AND DISCUSSION}

The geological substrate is the basis for formation of soil, where the plant cover is formed. By their decomposition, all the elements from the substrate reach soil and water and then through the food chain they reach plants, animals and humans. The researched territory is represented by two geological sheets (Figure $1)$.

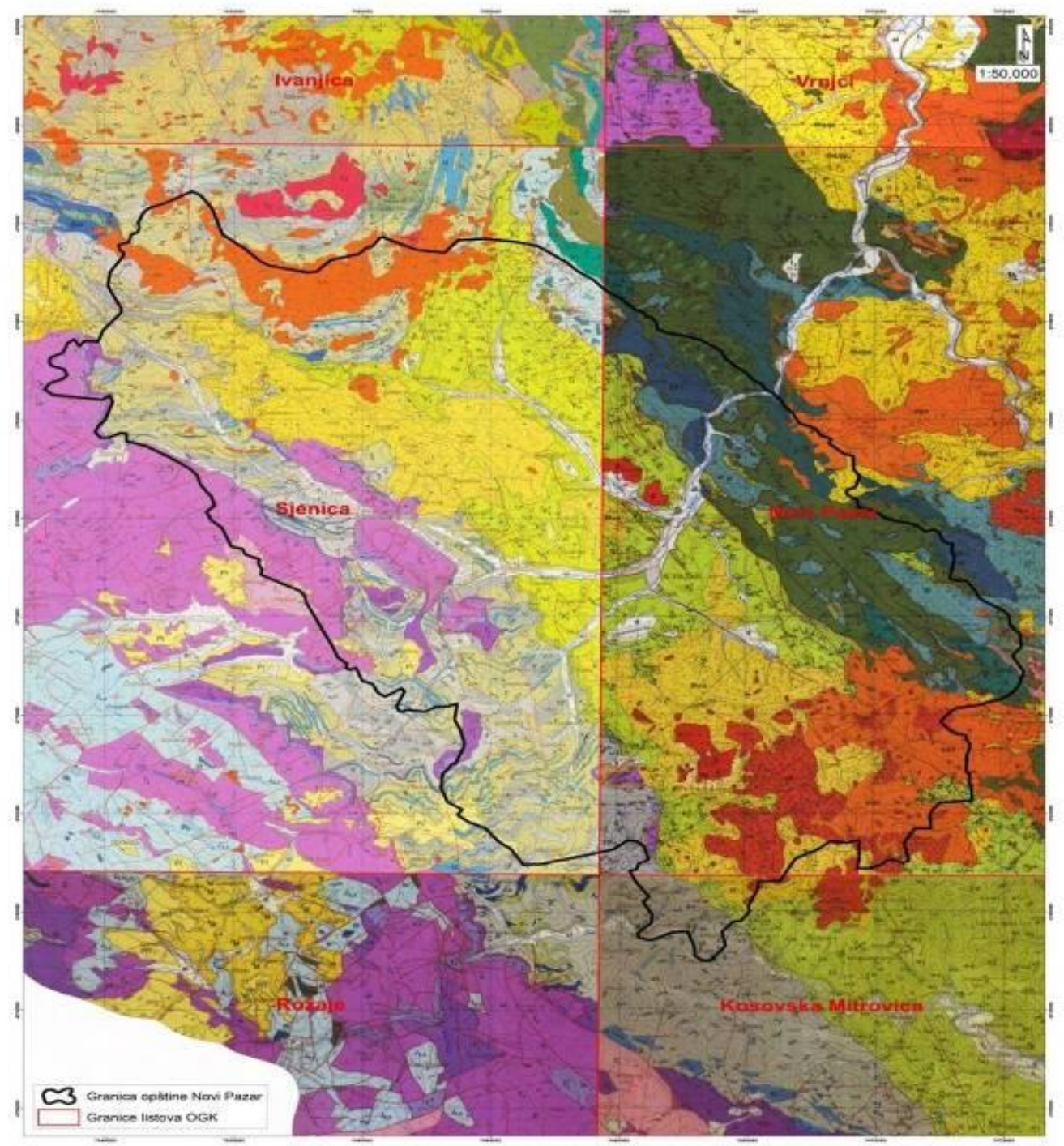

Figure 1. Geological map of the researched territory according to the Basic Geological Map 1:100.000, Sheet Sjenica (Mojsilović et al.,1979) and Novi Pazar (Urosević et al.,1970). 


\subsection{Geological Characteristics of the Sheet Sjenica}

"Sheet Sjenica" covers an area of 1,506 $\mathrm{km}^{2}$ and extends in southwestern Serbia, between 43 " 00 and 43 " 20 of latitude and 20 " 00 and 20 " 30 of longitude. Javor and Golija are in the north, Jadovnik and Giljeva in the west, southern border of the sheet is Pester-Tutin-Stari Kolasin, and eastern border reaches Novi Pazar and extends toward Golija. It is a mountainous region with an average altitude of over $1000 \mathrm{~m}$. Relief is rugged with significant differences in height. Sjenicko polje, Kostam polje and Pestersko polje stand out morphologically.

In this researched territory the following mapped units are singled out (Mojsilović et al.,1979):

- Low-grade metamorphic rocks of Paleozoic age discovered on the southern slopes of Golija and in the area of the Ljudska Reka river, as well as between Novi Pazar and Tutin. On the southern slopes of Golija, rocks have a very high crystallinity, which is a consequence of thermometamorphic action of quartz-latite and granodiorite masses.

- Quartz conglomerates and breccia form a narrow zone on the southern slopes of Golija and around Muhovo. They appear in the form of thick deposits. Their color is gray, rarely grayish brown. Sericite quartzite appears in the same area in the form of thinner layers.

- Phyllites extend in the area of Golija mountain, the Ljudska Reka and south from old Ras. Their color is gray, grayish brown and rarely almost black.

- Wide zone north and east from Muhovo, in the upper part of the Dezevska Reka river, in the Ljudska Reka river valley, then south of the village Gorandje and around Vrbasice, is made of sandstone, slate and phyllites.

- Sandstone is discovered around the village Gorandje, the Raska river valley, around Muhovo and in the area of Hodzevo.

- Plagiogranite is found in a small and narrow area in the village Orlje.

- Quartz clastites are found on location around Sopocani and Siljak, with a maximum depth of up to $120 \mathrm{~m}$.

- Oolitic limestone occurs to a lesser extent in Hodzevo and in the area towards Crkvine, with a maximum thickness of about $100 \mathrm{~m}$.

- Clayey and sandy limestones, stand out at the peripheries of Pestersko polje and Kostam polje in the valley of the Josanica, along the Novi Pazar -Tutin road and at Hodzevo.

- Spilite-keratophyre association, diabases are predominant among these rocks, then spilite, gabbro and keratophyre, while porphyrite is significantly rarer. Diabase breccias are found only in Golija.

- Porphyrite is found only on a few locations in sediments of diabasehornstein formation, namely on Golija and Bekova. Iron and manganese coatings give brownish red and ochre color. Metamorphosed diabasehornstein formation has been distinguished around Bekova and in Petrovo polje.

- Pre-flysch marl spreads in the valley of the Raska river around the village of Jablanica and on southeastern slopes of Golija. 
- Lower flysch horizon has been developed in the area of the Deževska river, then the Saronjska Reka river, between Novi Pazar and Sudsko Selo and north of Rajcinovica Banja.

- Sandstone horizon, developed in the Glavoc area, Musina Livada, Kalem village, northwest of Vojnice and in Boturovina. The thickness of these layers is about 300 meters.

- Pyroclastics are found in the area of Golija, the Ljudska Reka river, the Raska river, around the town of Novi Pazar and near Vojnice village.

- Terrace sediments are singled out on the map along the Raška and the Dezevska Reka rivers. Terraces into which the Raška river has cut its stream bed extend from Sopocani to Pazarište on both sides of the Raska river. Their maximum width is about $200 \mathrm{~m}$ and depth is 10 to $15 \mathrm{~m}$.

Terraces of gravel, sand and sandy clay, 5 to $10 \mathrm{~m}$ thick, have been formed along the Dezevska river.

- Diluvium and rock creeps are found in the valley of the river Ljudska Reka and in the Dezevska Reka. Their thickness varies from 20 to $30 \mathrm{~m}$.

- Proluvium is found on Pešter, then next to the Sebecevska Reka and the Ljudska Reka rivers, and its thickness is 20 to $30 \mathrm{~m}$.

- Alluvium is found along the Raška, the Ljudska and the Deževska rivers and its thickness is up to $30 \mathrm{~m}$.

\subsection{Geological Characteristics of the Sheet Novi Pazar}

"Sheet Novi Pazar" includes an area in the southwestern part of Serbia, between $20^{\circ} 30^{\prime \prime}$ and $21^{\circ}$ East longitude and $43^{\circ}$ and $43^{\circ} 20^{\prime \prime}$ North latitude. This territory is characterized by mountainous and high mountainous area with strong dissection and fine texture of relief. It includes central and southern parts of Kopaonik, Rogozna with Crni Vrh and southeastern parts of Golija. An overview of the territory of Rogozna and southeastern parts of Golija is presented in the paper:

- Significant area in the sheet Novi Pazar, namely the part from Novopazarska Banja to Odojevice, is rich in serpentinite.

- Quartzite also appears in the area of Golija and Rogozna mountains.

- Crystalline limestone occurs in the area of the Josanicka Reka. Its depth is 20 to $30 \mathrm{~m}$.

- Metamorphosed diabase is found on Cukara, where it forms smaller concordant lenses in phyllites.

- Conglomerates and conglomerate breccia are found in a larger area on the western slopes of Rogozna in the area of the villages Znusa and Belanjska. The thickness of a series does not exceed $50 \mathrm{~m}$.

- Marly limestone is noted in the Znuska Reka, Postenje and Blazevo. Its depth varies from 100 to $250 \mathrm{~m}$.

- Dacito-andesite and quartz-latite are noted in Lopuznje, Sanac and Javor.

- Quartz-latite and latite are noted around Cepeljski Krš, on Crni Vrh, in the village Bare and on Javor. 
- Basaltic andesite and trachybasalt are noted in the western part of Rogozna, Musov Vrh and Koznik.

- Alluvial formations are noted along river valleys of the river Raska, the Dezevska, the Josanica, the Trnavska.

If we analyze the territory of Novi Pazar, it can be concluded that significant majority of the area of its territory, in terms of geological substrate, is made of limestone and serpentinite, i.e. in the Sheet Sjenica limestone is predominant, while in the Sheet Novi Pazar the predominant substrate is serpentinite. These two geological formations affect differently the preservation of the environment by their decomposition. In the researched territory the environmental benefits which are a prerequisite for having unpolluted soil, clean and potable water, possibility for engaging in agriculture and forestry, development of spa tourism, as well as development of hunting, sports and health tourism must be reaped. (Hadrović, 2015).

\section{CONCLUSIONS}

The geological environment represents a very important component of the environment, its foundation. The degradation of rocks and minerals enables release of certain elements which then pass into lithosphere, hydrosphere and atmosphere and through the food chain that includes plants, animals and humans, these substances directly affect the health of plants, animals and humans.

The territory of Novi Pazar by its natural conditions represents one the most beautiful regions in Serbia. Surrounded on all sides by mountain ranges, with two spas with thermal mineral water and rich flora and fauna, it represents the right place for relaxation and development of all types of tourism. The geological substrate plays an important role in the above together with other environmental factors.

The geological composition of this territory dominated by limestone and serpentinite is conditioned by favorable geomorphological environment, abundance of thermal mineral water and high-quality potable water, which has favorable effect on quality and preservation of the environment.

\section{REFERENCES}

Bulmer, M. (1977): Sociological research methods, An introduction, second edition, Transaction Publishers, New Brunswick and London. (354).

Čokeša, V., Stajić, S., Miletić, Z. (2006): Contribution to the study of the effect of site and stand factors on the natural regeneration of beech in the area of Severni Kučaj, Sustainable Forestry Tom 54-55, Institute of Forestry, Belgrade, pp. 23-35.

Hadrović, S. (2015): Akumulacija ugljenika i azota u organskoj prostirci, šumskom zemljištu i šumskoj biomasi. Doktorska disertacija, Univerzitet "Union-Nikola Tesla" Beograd, Fakultet za ekologiju i zaštitu životne sredine, Beograd.

Komatina, M. (1999): Osnove medicinske geologije. Vesnik Geozavoda, knj.49, Beograd. 
Milosavljević, S., Radosavljević, I. (2008): Osnovi metodologije političkih nauka, Službeni glasnik, Beograd. (694).

Mojsilović, M., Đoković, D., Rakić, B. (1979): Osnovna geološka karta - list Sjenica, 1:100.000, Savezni geološki zavod, Beograd.

Neuman, W.L. (2014): Qualitative and Quantitative Approaches, 7th edition, Pearson Inc., Harlow. (599).

Urošević, M., Pavlović, Z., Klisić, M., Brković, T., Malešević, M., Trifunović, S. (1970): Osnovna geološka karta - list Novi Pazar, 1:100.000, Savezni geološki zavod, Beograd.

*** Opšta osnova gazdovanja šuma za Gornje ibarsko šumsko područje (2009-2019).

\title{
GEOLOGICAL SUBSTRATE OF THE TERRITORY OF NOVI PAZAR AS AN INDICATOR OF PRESERVED ENVIRONMENT
}

\author{
Sabahudin HADROVIĆ, Ljubinko RAKONJAC, Aleksandar LUČIĆ, Saša EREMIJA
}

\section{Summary}

The geological environment represents a very important component of the environment. The degradation of rocks masses enables release of certain elements which then pass into lithosphere, hydrosphere and atmosphere and through the food chain that includes plants, animals and humans, these substances directly affect the health of plants, animals and humans. Geological background and lands that it generated, as a set of environmental factors affect the divergence of plant forms and vegetation units. In addition to the chemical composition of the geological substrate, physical structures and quantitative relationship of individual elements and their salts in the substrate have a significant impact on vegetations that develop on that substrate, which is particularly well be seen when comparing the vegetation generated on different bedrocks and soils, as well as by comparative comparison of the chemical content of their representatives. The geological composition of territory Novi Pazar, dominated by limestone and serpentinite is conditioned by favorable geomorphological environment, abundance of thermal mineral water and high-quality potable water, which has favorable effect on quality and preservation of the environment.

\section{GEOLOŠKA PODLOGA PODRUČJA NOVOG PAZARA KAO INDIKATOR OČUVANE ŽIVOTNE SREDINE}

\author{
Sabahudin HADROVIĆ, Ljubinko RAKONJAC, Aleksandar LUČIĆ, Saša EREMIJA
}

\section{Rezime}

Geološka sredina predstavlja veoma važan sastavni deo životne sredine. Degradacijom stenskih masa, oslobađaju se pojedini elementi, koji potom prelaze u litosferu, hidrosferu, biosferu i putem lanca ishrane u kojem učestvuju biljke, životinje i čovek, direktno utiču na zdravlje biljaka, životinja i čoveka. Geološka podloga i na njoj nastala zemljišta, kao skup ekoloških faktora utiču na divergenciju biljnih oblika i 
vegetacijskih jedinica. Pored hemijskog sastava geološke podloge, na vegetaciju koja se na njoj razvija, značajan uticaj imaju fizička struktura i kvantitativan odnos pojedinih elemenata i njihovih soli u podlozi, što se naročito lepo može videti pri komparaciji vegetacija nastalim na različitim geološkim podlogama i zemljištima, kao i komparativnim upoređivanjem hemijskog sadržaja njihovih predstavnika. Geološki sastav područja Novi Pazar, gde dominiraju krečnjak i serpentinit, uslovljen je povoljnim geomorfološkim ambijentom, bogatstvom termomineralnih voda i voda visokog kvaliteta za piće, što se povoljno odražava na kvalitet i očuvanost životne sredine. 